\title{
State Power and Economic Inefficiency : Explaining Political Failture in Africa $^{1}$
}

\author{
E. A. Brett
}

Rural survival in Africa, as elsewhere, depends predominantly upon social rather than ecological factors once a division of labour between town and country has been established. The viability of the production process on the farm becomes a function of the effectiveness of the external structures which manage the interaction between them; more especially, that of the agencies, public and private, which guarantee property rights, supply inputs and market outputs. While there is much evidence to suggest that farmers, even the poorest and most ill-educated, will maximise their output when conditions permit, it is equally clear that production will decline when these processes of mediation break down.

This article attempts to confront the problem of agrarian failure as a problem of comparative institutional analysis rather than one of farm level organisation. To focus the argument it will concentrate upon the current debate about the relative merits of market-directed as opposed to state-directed forms of activity, and will attempt to treat both as a problem of public policy formation rather than economic analysis. In other words, it must be read as an exercise in political rather than economic theory.

\section{Choosing Alternatives: Public vs Private Provision}

An important element in the orthodox critique of African agriculture relates to the centrality of state controls in the supply of inputs and organisation of marketing. According to the Berg report:

The central problem in marketing and input strategy is the very general tendency to give too large a set of responsibilities to public sector institutions, and too few to other agents individual traders, private companies and farmers' cooperatives [World Bank 1981:58]

This paper is a revised version of one originally presented at the Political Science Association Conference, Manchester, 1985.
The effect of these monopolies has been said to be price distortions, excessive costs, inefficiency, low prices to the grower and a decline in output resulting from the corresponding lack of incentives. The alternative it to make the system 'more competitive' (p62), and in particular 'to capitalise on the existing trading system, a proven asset, and let it play a bigger role in the distribution system' (p64). The reasons for the inefficiency of state sector monopolies is not examined, while the power of competition as a means of guaranteeing the anticipated efficiency of the private sector producers is taken as a given. More especially, the faith in competition makes it possible to ignore entirely the organisational structure of the private sector agencies which are expected to perform these functions since, following the logic of neoclassical theory, it is assumed that if market competition is allowed to 'get the prices right' the capitalist entrepreneurs can be relied on to solve their own internal organisational problems. After all, only those actually capable of maximising profits by minimising costs will then be able to survive for long in the rigorous conditions established in the marketplace. Thus, although we see that the orthodox reform proposals start with an assertion of the need for a reform of both policy programmes and institutional structures, they end up being entirely lacking in any theory of either political intervention or administrative structure.

Most neo-Marxist critics of the African failure, on the other hand, do not share the orthodox enthusiasm for the market, but they, too, tend to associate centralised state control with the exploitation of the direct producers. Here we find a picture of a parasitic bureaucratic bourgeoisie appropriating surpluses for its own benefit and that of the foreign private bourgeoisie on which they depend for skills, technology and political reinforcement [e.g. Shivji 1976; von Freyhold 1979]. In this approach the functioning of institutional structures is the outcome of the overriding influence of the all-powerful international bourgeoisie, thus excluding an auto-

IDS Bulletin. 1986, vol 17 no 1, Institute of Development Situdies. Sussex 
nomous role for domestic elements in the political struggle, and eliminating any possibility of a progressive reform of the existing system short of some form of social revolution whose outcome they cannot anticipate. Here again, therefore, the possibility of a rational theory of political intervention within the existing structures of resource allocation is excluded.

I cannot attempt here to address all of the issues raised in these two approaches, nor to consider the role of external factors in the situation, whose significance is undeniable. What I do wish to suggest is that neither of them gives us any real understanding of the internal factors contributing to the emergence of the offending system, and that neither of them can therefore provide much help in the search for solutions. The lack of any adequate theory of political/institutional mediation in both approaches then simply compounds this problem. The neo-Marxist rejection of both market and bureaucratic solutions in favour of an ill-defined conception of democratic planning from below (in fact a retreat into nationalistic anarchism), thus provides no solution to the problem of restructuring the actual institutions upon which the immediate survival of the population depends. The orthodox model, on the other hand, simply asserts the superiority of the market solution on the basis of theoretical first principles, and makes no equivalent analysis of the conditions needed to reap the very real benefits which can undoubtedly be created by the development of efficient bureaucracies. After all, Weber's assertion that bureaucracy is, from a purely technical point of view, capable of attaining the highest degree of efficiency and is 'the most rational known means of carrying out imperative control over human beings', has yet to be effectively disputed [Weber 1947:337].

To do this we must first consider the way in which these state forms were created during the colonial period, then the nature of the transformation which they underwent as they were restructured by the new African ruling class. In both phases our concern in the first instance will be less with the economic rationality of the decision-making process, than with the nature of the class interests involved in the political struggle for control over resources. At the end of the day, after all, it is the political leverage exerted by those who control institutions which keep those institutions (however degenerate) in existence. Equally, the possibility of real reform must depend upon the capacity to mobilise real political support in the opposite direction, and not simply upon the production of rational economic models by the consultancy industry.

On the other hand, the failure of powerful class forces to generate effective solutions to social problems must itself be seen as the result of an attempt to use irrational and contradictory forms of social organisation for the purpose, and equally, no attempt at reform will succeed unless these failures can be theoretically understood and rectified. Thus the historical critique cannot be separated from the theoretical categories developed in the intellectual traditions which have formulated our models of market and bureaucratic organisation, nor can any treatment of possible alternatives.

\section{From Market to Monopoly in the Colonial Period}

The initial expansion of African cash crop production in the colonial era took place in a context in which private market allocations predominated. The peasant was forced to enter the market to pay taxes and secure imported consumer goods; their products and consumables were delivered by a hierarchy of private traders dominated at the top by a small group of European and Asian trading houses responsible for processing and foreign purchases and sales, and at the bottom by an array of intermediaries ranging from individual produce buyers with bicycles to relatively wealthy middlemen with access to lorries and storage space. The state apparatus provided very limited services directly to growers in the way of agricultural research, advice and technology, but was mainly important in relation to the maintenance of law and order and creation of infrastructure.

This almost classic laissez faire context in fact generated an extremely dynamic growth process in favoured regions within reach of external markets. Monopoly power on a voluntary basis was sometimes significant among the foreign merchant houses, a function of the concentration of capital in the large British trading houses associated with the organisation of cartels designed to limit competition for crops and thus keep down prices to growers [cf. Howard 1978]. Yet high profits drew new producers into this sector often from India and Lebanon, while the existence of a large and competitive petty trading sector maximised the tendency towards competition among the larger firms. The voluntary cartels organised by the dominant European companies therefore tended to collapse, threatening the high-cost firms with bankruptcy.

At their behest, therefore, the colonial state intervened more and more actively, particularly in the depression years, to control competition and guarantee a cost plus pricing system to even the least efficient producers [Brett 1973; Mamdani 1976]. During the war this monopolistic structure was further reinforced with the creation of state marketing boards with monopoly buying power and the right to set prices for both growers and intermediaries. During the 1940s 
this power was generally used to maintain very high profits for the expatriate marketing sector and to extract large surpluses for the state from the grower as raw material prices rose. The monopoly power allocated to the expatriate traders effectively destroyed the bargaining power of the independent indigenous buying agents, and the surplus extracted from the growers through the monopoly rents of both traders and state marketing boards meant that the direct producers were provided with neither the incentive nor the resources required to increase their output, with very negative results.

In effect a reactionary foreign merchant class now dominated the state, blocking the emergence of an indigenous merchant class and maintaining the peasant producer in a state of servile backwardness. The state, in the marketing board mechanism, now had additional means to extract surpluses from the direct producer, thus further reinforcing the fact that the most certain source of personal enrichment must be the capture of state power and the monopoly rents that went with it, rather than through the actual expansion of the forces of production.

By the later colonial period, therefore, the dynamism of the early laissez-faire period had been lost and a structure created which not only inhibited economic growth and social change, but also inevitably engendered the hostility of the major groups in colonial society. By so doing it simultaneously created the nationalist coalition and the post-colonial problems that this coalition was to find so difficult to resolve.

\section{The Nationalist Response: Nationalising the Monopolies}

The colonial monopolies described above excluded the small African petit bourgeoisie from access to the market and it imposed a structure of unequal exchange upon the peasantry. Further, this monopoly existed in the state apparatus as an exclusion of Africans from the higher levels of the administrative system and from the educational opportunities required to obtain the skills required to compete for them. As a result the intelligentsia, the commercial petit bourgeoisie and the peasantry could all be united in a common anti-colonial alliance, which could also expect the support of the small working class whose struggle over wages and conditions had brought them into conflict with their largely expatriate employers. For as long as colonialism continued, these disparate elements could be held together by their common opposition to one or other aspect of the racist power structure. Once in power, however, anti-colonialism had to be transformed from a negative critique into a positive developmental strategy - crops had to be grown, processed and sold; services had to be provided by the state; a new industrial sector created to provide the economy with a new dynamism. Yet none of this could be done without a new resource allocation which would inevitably generate sharp conflicts with the existing expatriate monopolies and within the alliance of domestic classes which constituted the nationalist coalition. If the expatriate power was sustained, the transition to independence would have had no effect and the new regime would soon become as unpopular as the old one; if the African petit bourgeoisie took over the existing monopolies it would soon inherit the hostility of the peasantry and working class and disrupt the nationalist alliance; if it failed to establish viable economic structures controlled by technically competent individuals (in very short supply among the indigenous population) production would break down and a serious regression occur.

The solution to this problem was seen to be the development of a socialist/populist strategy which, even in its most 'right-wing' variants, incorporated a central role for the state in relation to both overall regulation (called 'planning') and direct intervention in the production process itself. Since the state was now, through the democratic process, seen to be directly accountable to the indigenous population, and since its apparatuses were to be rapidly Africanised, it was widely assumed that it could be relied upon to institute a rational and non-conflictual development process which would restructure both a backward economy and a racist social structure. The 'socialist' orientation of the new strategy entirely eschewed any expropriation of indigenous property rights, treating these as 'pre-capitalist' and therefore no threat to egalitarianism. Instead it organised the extension of state control over the sphere of circulation (marketing, banking, services) and, in the 'left-wing' cases, over new areas of production, notably in secondary industry. Thus, the image of the post-colonial rural society was one in which the productive powers of a relatively egalitarian community of petty producers were to be organised on a non-exploitative basis by a rational and politically responsible, bureaucratic apparatus. Our prime theoretical concern must therefore be to explain the evident failure of this strategy, both as a mechanism for economic efficiency and for egalitarian distribution.

\section{Bureaucratic Failure in the Post-Colonial State}

The choice of this strategy, a function of the balance of class forces at the end of the colonial period, was based upon a set of assumptions about the pre-capitalist nature of the direct producers which constitute civil society, the rationality of formal public bureaucratic 
apparatuses, and about the nature of the interaction between them with respect to the generation of output and provision of services. The direct producers were presented as having undifferentiated needs whose fulfilment need not generate any significant contradiction between each other; the bureaucrats were assumed to have no internal class interest, only an interest in providing a service to others on the principles of formal rationality spelled out by Weber [1978] and Simon [1961]; finally, bureaucrats and direct producers were then expected to relate to each other on an arms-length basis, allowing each to perform their functions in accordance with the principles of autonomy and universal ism postulated in Parsonian sociological theory [Parsons 1951]. Unfortunately it soon transpired that none of these assumptions held, so the system very quickly demonstrated that it could not function as it should. By looking at the gap between these three ideal-typical assumptions and African reality we can therefore begin to produce some analytically rigorous explanations for this failure.

\section{(a) Bureaucracy and Peasantry}

Firstly, the notion of an undifferentiated peasantry capable of being equally served by a technocratic bureaucracy guided by the rational economic decisions of a national planning staff can be quickly disposed of. Long before the end of colonialism numerous inequalities had emerged within the African rural communities themselves and between one community and another. Differences in landholdings, technical competence and family size made some farmers far more successful than others, while differences in access to agricultural resources (land fertility and essential infrastructure like roads and schools) meant that some communities had prospered, others had fallen far behind. In a situation in which new resources were to remain scarce, these differences were to be translated into an intensely political struggle for what there was, a struggle which could not be rationally resolved through the application of some 'planning' logic.

Instead, the allocation of resources to African agriculture involved choices between strata and regions which enriched some and impoverished others, choices between backing a few 'progressive' farmers and a larger number of 'ordinary' ones; choices between building up the productive capacity of already strong areas and attempting to develop new ones whose needs were no doubt greater, but whose productive potential was as yet relatively unproven. In this situation planning decisions - presumably based upon the need to maximise the return to the investment of scarce resources - took on an intensely political significance; those of the agricultural administration, notionally based on technical rationality, equally so. Decisions about which inputs to use clearly altered the relative life chances of different categories of farmer - introduce exotic cattle and you confine benefits to the minority able to supervise them; upgrade local stock and you could perhaps reach a whole community. Build a road into one region, you put all its farmers into touch with the market; build it into another and you leave them isolated. And given that the whole society paid the taxes out of which the services were provided, the gains of the successful strata and regions were inevitably made at the expense of those which were overlooked.

When we look at the actual outcome of this process we find massively unequal allocations and a corresponding intensification of political conflict as a result. Within regions, a strong bias towards western capital intensive technology reinforced and extended the power of large farmers as against small ones. Here the desire of Western aid donors to sell their own technology coincided with the desire of the large farmers to upgrade their own activities. Hence the bulk of the new investment went into mechanical technology, complex farming systems, and exotic livestock for a tiny minority, while the mass of the poor peasantry were left to continue with what they had had before. Regionally, the resource allocation pattern depended upon the origins of the groups which had captured political power at the centre; almost always this left some areas unserviced and deepened their underdevelopment.

Needless to say, both of these processes created powerful political tensions. Since the mass of the peasantry gained virtually nothing from the new structure, their support for the nationalist alliance soon collapsed, leading to the disintegration of most of the political parties which had organised the transition to self-rule. Given the inequality in regional allocations, it is also hardly surprising that tribal conflicts intensified and often violent separatist movements were common. The existence of these tensions both inside and between regions therefore undermined links between periphery and centre and destroyed the assumption that the state could be relied on to serve the needs of the whole people. Having begun as an agency captured from the colonialists on behalf of the nation, it had come to be seen as a mechanism for the extraction of surpluses from many for allocation to an increasingly favoured few.

\section{(b) Bureaucratic Rationality and Particularistic Demands}

Secondly, the role and structure of the civil service itself in the development process, modelled upon that of the social democratic interventionist state in 
Europe, could not be sustained in the ambiguous context of society undergoing a transition from a colonial and predominantly pre-capitalist structure. The Weberian model of a service bureaucracy presupposed a group of officials appointed by merit, differentiated and stratified by function and skill, capable of achieving least-cost solutions to problems through the application of scientific knowledge. Having been thus identified, the civil servant will then be paid an adequate wage to compensate him/her for the disabilities involved in having to accept the organisational constraints involved in performing the task. It is therefore assumed that a stratum of people will exist in the society to fill these positions with the necessary skills and motivated to perform the task in this impersonal way. Most especially, these individuals should not regard their control over administrative resources as a means for personal, family or class enrichment nor as a method of exerting social control over civil society itself. The administration is to serve as a means to political ends identified through the political process, not as an instrument of political control.

Now the most obvious difficulty at independence in this regard was the absence of 'trained' personnel, trained in the academic skills considered essential for the decision-making levels of administrative structures from which Africans had previously been excluded; trained in the motivational understanding required to develop the sense of vocation which would ensure a proper willingness to put service above self. The limited size of the pool of indigenous graduates was widely publicised, as was the necessity to promote under-trained personnel from middle-level into higher-level positions. To deal with this problem an immense effort was put into public administration training, with a leading role being played by aidfinanced institutions which were designed to teach Western (and largely American) public administration theory to the new personnel [Schaffer 1974].

No doubt this problem was a serious one, but probably not the most important source of subsequent difficulties. By the end of the 1960s a number of African countries - for example Ghana, Nigeria, Uganda and Senegal - had produced a substantial cadre of graduate administrators with the training and skills which would have equipped them to perform their technical functions perfectly adequately in most Western bureaucracies. What was more problematic about their situation was the nature of the relationships between resources they earned and controlled as civil servants and their class position in the wider society.

Firstly, although recruited for the most part from the most prosperous regions and strata within colonial society, control over a senior civil service position involved an immense jump in status, wealth and power for the individuals concerned. The lack of a developed indigenous capitalist class and the dominant economic role accorded to the administration, meant that these positions were seen to be uniquely desirable, and to put their incumbents in control of an immensely powerful set of resources - a very large regular income, patronage in appointments, overseas travel and contacts, the power to award contracts, allocate developmental resources, and grant access to a wide array of very scarce services. And although security of tenure and pension rights at least notionally guaranteed the incumbent long-term security, it could not provide for all of the needs of a complex and extensive family network which remained in the petty commodity producing class. Hence the immense resources were immediately subjected to an equally immense set of demands on the part of relatives and clients who could hardly be expected to be satisfied to remain subordinate. Thus, confronted with a set of demands for assistance far more urgent and extensive than those experienced by their counterparts in the West (where senior bureaucrats are for the most part recruited from wealthy and high status strata), it was inevitable that their decisions would come to be powerfully influenced by personal and particular considerations.

Secondly, the African civil servant was recruited from a society of petty producers and retained his/her control over productive assets there. Being placed in direct control of the resources to be provided by the state to direct producers, it was inevitable that these should be used to extend their own private economic power and that of their kinship network. Salaries could be used to buy land, special access arranged to state credit schemes, preferential use made of critical resources like tractors, and so on. The political leadership and senior civil servants (including army officers) thus became deeply enmeshed in the struggle for resources described above, a struggle essentially intended to transform them into an indigenous capitalist class. In effect we can see that control over the resources appropriated through the economic coercive power of the state was being used as a mechanism of primitive accumulation, to become 'a point of departure' [Marx 1976:873] for the creation of capitalist production relations in a community previously excluded from them by the racist monopolies of colonialism.

In this process the universalistic civil service norms were often treated with contempt. Again, of course, these temptations do not present themselves in the same way to their Western counterparts. In these contexts the concentration of capital and existence of developed employment opportunities for the whole of 
the educated stratum means that primitive accumulation of this kind is neither necessary nor possible. In the African context, however, the pressure to 'misuse' power for personal and family benefit was unremitting since the rewards of success were so large, and the costs of failure to individuals left struggling in the petty producing class, so heavy.

\section{(c) Bureaucratic Planning, Monopoly Rents and Economic Inefficiency}

Thus, we can see that neither the concept of undifferentiated peasant community nor that of disinterested servant of the state and people was an adequate description of either the direct producers or the bureaucrats paid to service them. This being so, it also follows that the interaction between them will have failed to conform to the rational planning model on which it was supposedly based. Bureaucratic delivery based upon state enforced monopoly powers involves a rejection of market allocation where access to inputs and outputs is rationed by prices reflecting the relative scarcity of factors of production and consumer goods. Access to both (and therefore control over economic power) is therefore allocated impersonally, and a function of technical competence and control over the capital assets required to produce in a given technological context. The market may enable new producers to emerge and established producers to disappear, but it will not generate equality of rewards or of opportunity. On the contrary, competition is designed to give everyone not what they need but what they deserve, on the assumption that real incentives and sanctions are needed to guarantee maximum performance. The rationality of the market system, and its legitimacy, therefore rests upon the impersonality through which its agents are rewarded for satisfying expressed needs, and upon the existence of formal equality of access and of insecurity [Macpherson 1962]. Here prices must reflect the real cost of factors and of labour because anyone capable of using them more economically will have been free to enter the market and to make them available.

The insecurity and inequality generated by market competition has produced the range of interventionist theories from Keynesianism to statism designed to use political authority to redistribute resources in a manner which will offset these tendencies. All of these involve two related elements - the acceptance of a central political decision to offset a result which would otherwise have occurred as a result of individual interaction, and the creation and allocation of a monopoly rent. The legitimacy and economic efficiency of this decision will then depend upon the adequacy of the process through which it is arrived at, and of the productivity of any new investments which it might finance. Where planning involves a centralised decision, the aggregation of preferences can only be accepted as legitimate where democratic procedures exist to control the planners [Arrow 1963]. Where planners tax existing producers to finance new activities, growth will only be greater where it can be shown that the alternative activities will be more productive than existing ones in the long run. Where, on the other hand, the monopoly power of the state is used to appropriate rent without consultation, and then allocate it to non-productive or less-productive activities than would be the case otherwise, we can expect a collapse both of political authority and of economic stability and growth. And there can be little doubt that it has been the latter, rather than the former model which has prevailed in most of tropical Africa over the past 25 years.

In the colonial period it was the monopoly rents extracted by the expatriate merchant and settler classes which inhibited the further development of the productive forces after the export economy had been created. The transition to independence and the creation of democratic structures suggested that the planning process could be brought under social control and turned into an engine for the sort of growth stimulated by the social democratic experience of Western Europe in the 20 years after the war. But it is now clear that this model, and in particular the bureaucratic structures derived from it, was entirely inappropriate in the context we have described, where monopolistic state power, exercised by a new bureaucratic class, was expected to determine the relative needs of an extensive class of atomised petty producers, and to find some rational basis on which to allocate resources to them.

In a situation in which procurement, land rights and the allocation of inputs are in the hands of state agencies, and where they also appropriate surpluses in the form of taxes, marketing board profits (or excessive costs) and foreign exchange allocations (based on non-convertible currencies and over-valued exchange rates), the problem of democratic supervision of the planning process becomes an immensely difficult one. Highly technical calculations are inevitably involved, and an immense array of hidden mechanisms exist through which strategically located interests can appropriate rents and destroy potential competitors. And where the community of producers is hardly literate, widely dispersed, out of touch with public information, and divided internally by the forces of competition, the possibility of ensuring that their political representatives sustain an adequate control over the allocation process is almost non-existent.

Equally important, their political representatives, and, as we have seen, the bureaucratic cadre itself, 
were themselves recruited from the upper stratum of the peasant community and concerned to use their political control to maximise their own economic gains within the competitive struggle for economic resources. In a pure market situation political power would not serve this purpose, since accumulation would depend directly upon the capacity to buy and to sell. But the complex and extensive system of expropriations, subsidies and direct allocations which constituted the structure of state intervention in the African context could have been expressly designed as a mechanism for primitive accumulation by the political and bureaucratic class. In some cases the subventions were direct - as where large farmers were provided with heavily subsidised land-clearing and ploughing services. In others they were indirect and depended upon the scarcity value of a community being offered at a subsidised price. In these cases the bureaucrat could exploit the situation by demanding a bribe to guarantee delivery, and thus appropriate a proportion of the monopoly rent. In both cases, moreover, the possibility of appropriation through the manipulation of state power was a function of the existence of prices which did not reflect the real costs of the assets involved; had they been set at the level corresponding to market value the link between direct political control and surplus extraction would have been severed.

In this context, therefore, the political/bureaucratic class developed a vested interest in sustaining the price distortions which allowed them to control surpluses and use them to strengthen their economic and/or political power. Where it can be shown that these distortions are generating an accumulation process with positive results, the mere fact that market rationality has been overturned need not cause us any concern. But the African evidence as to the irrationality of the great majority of bureaucratic decisions is overwhelming. It is impossible here to document this assertion, but the evidence is easy to find in grossly over-extended civil service payrolls; pricing policies which left the direct producers with virtually nothing and caused them to stop cash-crop production; investment in largely useless capital intensive technology for a minority of inefficient largescale producers, while the mass of small producers get virtually nothing; the building of expensive prestige projects in towns while the rural infrastructure collapses; the subsidisation of uneconomic industry to the point where the cost of the inputs was higher than the value of the corresponding imported finished products.

In this process a limited fraction of the aspirant petit bourgeosie made substantial gains and translated them into immense wealth, but at the expense of the political integrity and economic coherence of the system as a whole. At the same time, almost all of the gains were secured at the expense of the small-scale direct producers whose output earned the foreign exchange and supplied the domestic market with essential inputs, particularly of food. Being atomised politically and disorganised economically, this class has been unable to respond to this attack through the creation of a political movement capable of representing its interests and enforcing a change of priorities at the centre. Instead, it reacted by reducing production and, more especially and more interestingly, by diverting it into the 'black economy'.

Having become a mechanism for surplus extraction rather than service provision, the state now finds its activities increasingly bypassed. Goods are smuggled across borders; currencies change hands at unofficial exchange rates; official marketing agencies are ignored and goods exchanged by unlicensed traders at fully negotiated prices. Having attempted to use state controls to displace the free market, the former finds itself increasingly marginalised by the re-emergence of a market system over which it has lost almost all control.

This process has developed to different degrees in different countries, but its negative consequences can be seen at work everywhere. Those which have been damaged by it least are probably the ones which have imposed fewest limits upon the private investment activities of the accumulating class. Thus, the recent debate on the emergence and potential of a "national bourgeoisie' in Kenya is a response to the evident success of the dominant political class there in using its appropriations to create at least some relatively successful capitalist enterprises in agriculture and industry [Swainson 1980; Leys 1978; Kaplinsky, Henly, Leys 1980]. On the other hand, perhaps the greatest structural problems have emerged in countries like Tanzania, where the commitment to state intervention involved, in addition, the forcible repression of a wide range of private capitalist interests. Here state failure has meant that production has fallen significantly over the past decade [Coulson 1982].

In the longer term, this failure of state planning has discredited the confident predictions of the 'left' at the end of the 1960s when it asserted that it was to be the state-controlled economies like Tanzania as opposed to the capitalist dominated ones like Kenya, which were going to be the most likely to succeed. It is now being used in the now dominant economic literature [e.g. Little 1982] and by the IMF and World Bank [Guitian 1982; World Bank 1979] to reassert the orthodox liberal case in favour of privatisation and market rationality. 


\section{Conclusions: Back to and Beyond the Market}

The analysis presented here has clearly been powerfully influenced by these developments, and also suggests that in many contexts the poor and middle peasantry would be better off if a substantial part of the state apparatus was dismantled and replaced by private enterprise, provided that the entrepreneurs concerned were subjected to market competition and not provided with the monopoly powers given to their expatriate predecessors in the colonial period. But it would be wrong to treat this analysis as no more than a case for a return to market forces, since it is by no means clear that this would safeguard the rights and productive capacity of the poor peasantry. In a context in which there is already a substantial degree of inequality, in which the dominant strata in the countryside are capable of using their social and economic power to enforce the support of the rest, market forces, too, could act to reinforce inequalities and hasten the disintegration of the property rights of a large proportion of the poor. Although state structures can be shown to have exploited the peasantry ruthlessly and inefficiently, it does not follow that the latter are likely to prefer the exploitation of a capitalist merchant and financial class very much more. Rural populism in many countries has almost always been strongly anticapitalist because of the insecurity of the agricultural production process and the perceived (whether rightly or wrongly) exploitativeness of the traders and banks.

My own concern in this analysis has been to demonstrate the inadequacy of the view of the bureaucratic process in the social democratic theory which served to validate the interventionist policies of the 1960s and early 1970s, not in order to legitimate a return to the market, but to demonstrate the need for the creation of politically controlled structures for economic intervention which would meet the real needs of a community of small-scale producers of the African type. Clearly the Weberian bureaucratic model does not meet these needs. Instead we have to ask how far and in what ways control over these structures can be decentralised to the local level, and political and economic accountability enforced. Here it may well be that cooperative and/or voluntary organisations supported by the state, organised on democratic principles, and operating in a context in which they had to compete on the market with organisations of the same kind and the private sector as well, would be far more appropriate than the statist agencies which have dominated the scene up to now. There is no space here to take up the many complications which these alternatives suggest; there can be no doubt at all, however, about the need for a far more rigorous critique from the left of the inner dynamic of the orthodox bureaucratic model in Africa (and perhaps elsewhere) than we have had hitherto.

\section{References}

Arrow, K. J., 1963, Social Choice and Individual Values (2nd ed.), Yale, New Haven

Brett, E. A., 1973, Colonialism and Underdevelopment in East Africa, Heinemann, London

Coulson, A., 1982, Tanzania: A Political Economy, Clarendon, Oxford

Guitian, M., 1982, 'Economic management and International Monetary Fund conditionality', in T. Killick (ed.), Adjustment and Financing in the Developing World, IMF/ODI, Washington DC

Howard, R., 1978, Colonialism and Underdevelopment in Ghana, Croom Helm, London

Kaplinsky, R., C. Leys and J. Henley, 1980, 'Capitalist accumulation in the periphery - the Kenyan case re-examined', Review of African Political Economy, 17

Leys, C., 1978, 'Capital accumulation, class formation and dependency: the significance of the Kenyan case', Socialist Register

Little, I. M. D., 1982, Economic Development, Basic Books, New York

Mamdani, M., 1976, Politics and Class Formation in Uganda, Heinemann, London

Marx, K., 1976, Capital, vol 1, Penguin, Harmondsworth

Parsons, T., 1951, The Social System, Free Press, Glencoe

Schaffer, B., 1974, Administrative Training and Development, Praeger, New York

Simon, H. A., 1961, Administrative Behaviour (2nd ed.), Macmillan, New York

Shivji, I., 1976, Class Struggle in Tanzania, Heinemann, London

Swainson, N., 1980, Corporate Capitalism in Kenya, Heinemann, London

von Freyhold, M., 1979, Ujamaa Villages in Tanzania, Heinemann, London

Weber, M., 1978, Economy and Society, University of California Press, Berkeley

World Bank, 1981, Accelerated Development in sub-Saharan Africa (The 'Berg' Report), Washington DC 